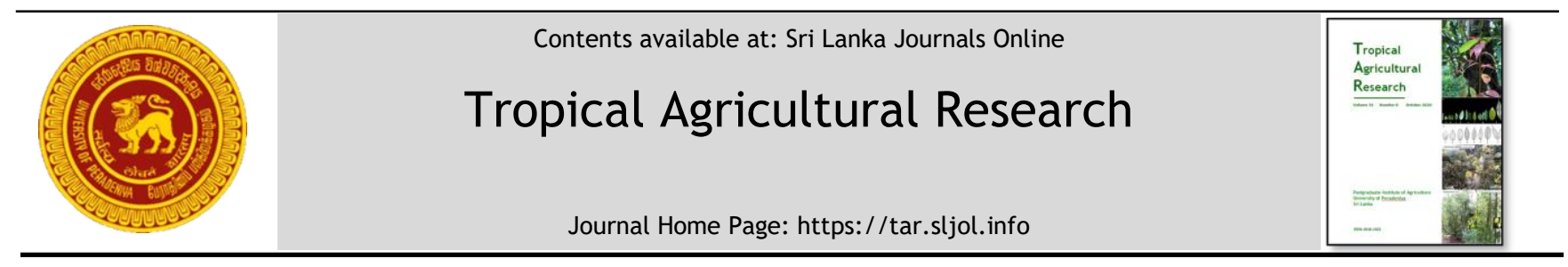

\title{
Exploring the Yield Response of Paddy (Oryza sativa L.) under Varying Levels of Soil Nitrogen, Phosphorus and Potassium
}

\author{
H.P.G.T.N. Kulasinghe ${ }^{1}$, U.W.A. Vitharana ${ }^{2 *}$, R.S. Dharmakeerthi' ${ }^{2}$, D.N. Sirisena ${ }^{3}$ and W.M.U.K. \\ Rathnayake ${ }^{3}$ \\ ${ }_{1}^{1}$ Postgraduate Institute of Agriculture, University of Peradeniya, Peradeniya, Sri Lanka. \\ ${ }^{2}$ Department of Soil Science, Faculty of Agriculture, University of Peradeniya, Peradeniya, Sri Lanka. \\ ${ }^{3}$ Rice Research and Development Institute, Department of Agriculture, Batalegogda, Sri Lanka.
}

\section{ARTICLE INFO}

\section{Article history:}

Received: 20 August 2019

Accepted: 30 October 2019

Revised version received: 09 September

2020

Available online: 1 October 2020

Keywords:

Paddy

Phosphorus

Potassium

Variability

Yield Response

\section{Citation:}

Kulasinghe, H.P.G.T.N., Vitharana, U.W.A., Dharmakeerthi, R.S., Sirisena, D.N. and Rathnayake, W.M.U.K. (2020). Exploring the Yield Response of Paddy (Oryza sativa L.) under Varying Levels of Soil Nitrogen, Phosphorus and Potassium. Tropical Agricultural Research, 31(4): 01-12.

DOI: http://doi.org/10.4038/tar.v31i4.8416

Kulasinghe, H.P.G.T.N.

https://orcid.org/0000-0003-3462-3831

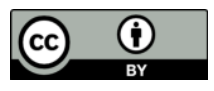

\section{ABSTRACT}

Assessment of crop responses under varying levels of soil available nitrogen $(\mathrm{N})$, phosphorus $(\mathrm{P})$ and potassium $(\mathrm{K})$ is important to develop site-specific nutrient management (SSNM) strategies. This study was conducted to investigate the spatial variability of soil $\mathrm{N}, \mathrm{P}$ and $\mathrm{K}$ levels in paddy grown soils in Anuradhapura, Kurunegala and Polonnaruwa districts and corresponding yield response for nutrient application. Seventy-one paddy fields were selected and four plots $(3 \times 6 \mathrm{~m})$ were established at each site comprised of a treatment applied with ample amount of $\mathrm{N}, \mathrm{P}$ and $\mathrm{K}$ and corresponding omission treatments. At harvesting, total yield of each plot was recorded. Considerable heterogeneity of soil N (12.5-43.9 mg/kg), P $(2.7-34.2 \mathrm{mg} / \mathrm{kg})$ and $\mathrm{K}(14.6-221.9 \mathrm{mg} / \mathrm{kg})$ was observed in paddy grown soils of the three districts. A significantly higher average yield of $\mathrm{N}$ applied treatment $(5.8 \mathrm{Mg} / \mathrm{ha})$ than that of $\mathrm{N}$ omitted treatment $(3.9 \mathrm{Mg} / \mathrm{ha})$ indicated a yield response for $\mathrm{N}$ application. However, nonsignificant differences of average yields of $\mathrm{P}(5.7 \mathrm{Mg} / \mathrm{ha})$ and $\mathrm{K}(5.6 \mathrm{Mg} / \mathrm{ha})$ omitted and ample treatments (5.8 $\mathrm{Mg} / \mathrm{ha}$ ) revealed a poor yield response for the application of these nutrients. Stepwise multiple regression analysis revealed that neither the initial soil $\mathrm{P}$ and $\mathrm{K}$ levels nor the other studied factors (growing season, irrigation scheme, soil texture, $\mathrm{pH}, \mathrm{EC}$, available $\mathrm{Fe}$ and $\mathrm{Mg}$ ) have an impact on yield responses observed for $\mathrm{P}$ and $\mathrm{K}$ applications. Our results indicated large spatial heterogeneity in soil $\mathrm{P}$ and $\mathrm{K}$ levels in paddy grown soils. Absence of a significant response for the applied $\mathrm{P}$ and $\mathrm{K}$ and a considerable variability of yield responses highlighted the need of further studies on $\mathrm{P}$ and $\mathrm{K}$ reserves of paddy growing soils and factors controlling the variability in yield response. Further, site-specific application of $\mathrm{N}$ is shown as a priority to improve the productivity of paddy lands.

*Corresponding author : uvithara@agri.pdn.ac.tk 


\section{INTRODUCTION}

Blanket recommendations-based application of inorganic fertilizers often causes imbalances in the supply of soil nutrients to the crop and leads to negative impacts on the environment (Doberman et al., 1998). Many studies have revealed that site-specific nutrient management (SSNM) as a viable alternative to optimize the fertilizer use efficiency while enhancing profitability of paddy crop (Doberman et al., 2002; Pampolino et al., 2007) and minimizing negative environmental feedbacks. Identifying the crop response for varying levels of available soil nutrients is a key step in determining the site-specific fertilizer requirements.

Studies conducted in Sri Lanka have revealed a poor response for added $P$ (Wickramasinghe et al., 2009; Sirisena et al., 2013) and K (Bandara et al., 2009) nutrients. However, many of these findings are localized to soil conditions prevail in research stations. Vitharana et al. (2019) showed a significant spatial variability of properties of soils of Sri Lanka. Witt et al. (1999) reported that localized researches conducted at research stations often lead to conclusions that are not valid for larger geographical context. Therefore, while capturing the spatial variability of soils there is a need of extending these localized findings of nutrient response behaviours of paddy crop to different paddy growing environments. In this study, we hypothesized that nutrient response information gathered through a large number of on-farm field experiments in diverse paddy growing environments would provide better understanding of nutrient response of paddy growing soils of Sri Lanka. Objectives of this study were to investigate the spatial variability of soil $\mathrm{N}, \mathrm{P}$ and $\mathrm{K}$ and yield response for fertilizer application in paddy grown soils in Kurunegala, Anuradapura and Polonnaruwa districts.

\section{MATERIALS AND METHODS}

\section{Description of study sites}

A series of experiments were conducted in three districts of Sri Lanka, Kurunegala Anuradhapura and Polonnaruwa, for three consecutive seasons, Yala 2017, Maha $2017 / 18$ and Yala 2018. Yala season is comparatively dryer season, with less rainfall than the Maha season. Selected areas represented two major paddy growing environments, Dry (mean annual rainfall $<1750 \mathrm{~mm}$ ) and Intermediate zones (mean annual rainfall $1750-2500 \mathrm{~mm}$ ). Alfisol is the major paddy growing soil order that can be found in these two zones. Total number of 71 experimental sites, each with an area of approximately $200 \mathrm{~m}^{2}$, were identified from the three districts (Figure 1) where rice-rice cropping system is practiced. Except one site, all other sites were cultivated under irrigated conditions.

\section{Field experiment layout}

Four experimental plots ( $3 \mathrm{~m} \times 6 \mathrm{~m}$ ) were established in each site. Treatments were consisted of $\mathrm{N}, \mathrm{P}$ and $\mathrm{K}$ omission plots and a plot applied with ample amount of nutrients. The ample treatment plot was applied with Urea, Triple Super Phosphate and Muriate of Potash at rates of $330 \mathrm{~kg} / \mathrm{ha}, 130 \mathrm{~kg} / \mathrm{ha}$ and $115 \mathrm{~kg} / \mathrm{ha}$, respectively. Omission treatment plots were applied in ample quantities of nutrients except the omitted nutrient. Treatment plots were arranged randomly with a single replicate.

Plots were irrigated by the main water supplying channel to minimize nutrients input from neighbouring fields. Direct seeding was practiced in puddled soil, irrigated adequately to maintain the water level optimum for paddy growth at different growth stages. Rice varieties $\mathrm{Bg} 352$ and $\mathrm{Bg}$ 300 were used in 62 and 6 sites, respectively and other 3 sites were cultivated with the variety Bg 367 . Weed management, pest and disease control measures were undertaken. 


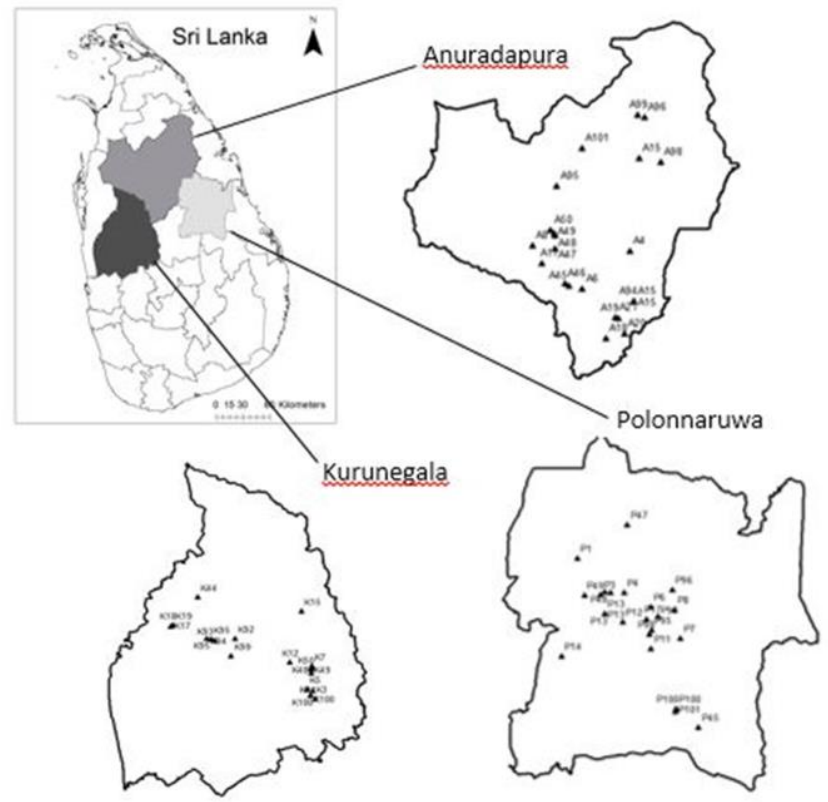

Figure 1: Field locations of the selected sites of Kurunegala, Anuradhapura and Polonnaruwa districts.

The plots were harvested and total yield of each plot was recorded at the end of the growing season. Two sub samples were taken from each plot for the laboratory measurement of grain moisture and grain yields were reported at $14 \%$ moisture content.

\section{Soil analysis}

Before the commencement of the growing season, a composite surface soil $(0-20 \mathrm{~cm})$ sample was collected from each experimental site. Samples were air dried and sieved using a $2 \mathrm{~mm}$ sieve before the laboratory analysis. Available $\mathrm{P}, \mathrm{K}, \mathrm{Mg}$ and $\mathrm{Fe}$ were extracted using the Mehlich (III) extractant. Available P was determined using spectrophotometry based ascorbic acid method (Murphy and Riely, 1962) and available K was measured using flame spectrophotometry. For the interpretation of fertility status, Mehlich (III) soil $P$ values were converted to Olsen $P$ values using the following equation (Mallarino, 1995),

Olsen $P$ concentration $(\mathrm{mg} / \mathrm{kg})=2.1+0.47 \times$ Mehlich (III) P concentration (mg/kg).
Available $\mathrm{Mg}$ and Fe were analyzed by atomic absorption spectrophotometry. Fresh soil samples were extracted with $2 \mathrm{M} \mathrm{KCl}$ and analysed for available $\mathrm{N}\left(\mathrm{NH}_{4}-\mathrm{N}\right.$ and $\mathrm{NO}_{3}-$ $\mathrm{N})$ using a Continuous Flow Analyzer (SKALAR $\mathrm{San}^{++}$). Soil pH and EC of each soil sample were determined in 1:2.5 soil/water suspensions, using a $\mathrm{pH}$ meter (Eutech $\mathrm{pH}$ 700) and EC meter (Eutech COND 6+). Soil texture was determined by pipette method (Van Reeuwijk, 2002). Soil total carbon content was analysed using the $\mathrm{CN}$ analyser (SKALAR Primacs ${ }^{\mathrm{SNC}-100}$ )

Variability of soil fertility parameters could be due to both inherent variability in soils and difference in soil management practices by farmers (Buresh, 2015). Thus, a farmer survey was also conducted to obtain information on fertilizer management. Sixtyfive paddy cultivating farmers participated in the survey. Through a systematic questionnaire, information on present yield, fertilizer management, irrigation, residue management and previous crop management were gathered. Further, Irrigation water samples were collected from nine experimental sites during the growing season to determine the $\mathrm{K}$ concentration. Water 
samples were collected from the canal at the tillering stage of the crop.

\section{Statistical analysis}

Exploratory data analysis was performed using SPSS statistical software (SPSS Inc, 2009). Paired sample $t$-test was conducted using SPSS statistical software to compare the mean yield between the ample treatment and nutrient omission treatments. The yield of omission treatment plots were plotted against the respective yields of ample treatment plots (scatter plots) to identify the yield response for each nutrient. Stepwise multiple linear regression analysis was performed to identify factors which affect the yield response for added $\mathrm{P}$ and $\mathrm{K}$, using SPPS statistical software.

\section{RESULTS AND DISCUSSION}

\section{Spatial variability of available soil N, P and $K$}

Soils of majority (52\%) of sites had medium level of available $\mathrm{P}(5-10 \mathrm{mg} / \mathrm{kg})$ whereas $31 \%$ of sites were low $(<5 \mathrm{mg} / \mathrm{kg}$ ) and $17 \%$ of sites were high (>10 mg/kg) in available P. Available soil $\mathrm{K}$ level was very high $(>160$ $\mathrm{mg} / \mathrm{kg})$ in $8 \%$ of sites, high $(80-160 \mathrm{mg} / \mathrm{kg})$ in $62 \%$ of sites, medium $(40-80 \mathrm{mg} / \mathrm{kg})$ in $24 \%$ of sites and low $(<40 \mathrm{mg} / \mathrm{kg}$ ) in $6 \%$ of sites. The coefficient of variation (CV) of the available soil $\mathrm{N}, \mathrm{P}$ and $\mathrm{K}$ levels were $30 \%$, $78 \%$ and $41 \%$, respectively (Table: 1 ). These CVs indicated a high spatial variability of available nutrients in paddy growing soils of the three districts. Several studies conducted in paddy growing soils of the dry zone, showed high spatial variability of available soil $\mathrm{P}$ and $\mathrm{K}$ levels (Sirisena et al., 2008; Rathnayaka et al., 2015).

Table 1: Summary statistics for available soil N, P and K.

\begin{tabular}{|c|c|c|c|c|c|c|c|c|}
\hline & $\begin{array}{c}\text { Mean } \\
\text { (mg/kg) }\end{array}$ & $\begin{array}{l}\text { Median } \\
\text { (mg/kg) }\end{array}$ & CV & $\begin{array}{c}\text { Min } \\
\text { (mg/kg) }\end{array}$ & $\begin{array}{c}\text { Max } \\
\text { (mg/kg) }\end{array}$ & $\begin{array}{c}\text { SD } \\
\text { (mg/kg) }\end{array}$ & Skw. & Kurt. \\
\hline $\mathrm{P}$ & 8.43 & 6.78 & 78 & 2.72 & 34.2 & 6.63 & 2.55 & 6.83 \\
\hline $\mathrm{K}$ & 101.20 & 103.43 & 41 & 14.63 & 221.93 & 41.95 & 0.13 & -0.08 \\
\hline $\mathrm{N}$ & 24.52 & 23.6 & 30 & 12.5 & 43.99 & 7.6 & 0.79 & 0.29 \\
\hline
\end{tabular}

(SD: Standard deviation, CV: Coefficient of variation, Min: Minimum, Max: Maximum, Skw: Skewness, Kurt: Kurtosis)

Spatial variability of soil nutrients is caused by the variability of inherent soil characteristics that influence the nutrient availability as well as by the heterogeneity of soil management practices. The summary of the soil management information collected through the farmer survey is summarized in Table 2. The Department of Agriculture, Sri Lanka recommends the application of fertilizers as five split doses at critical times of the growing season (Sirisena, 2013). However, many farmers have deviated from the recommendation (Table 2) and a large proportion of farmers $(>90 \%)$ practiced the application of fertilizers for three to four times. Average fertilizer application rates of Urea, Triple Super Phosphate (TSP) and Muriate of Potash (MoP) were $204 \mathrm{~kg} / \mathrm{ha}$ (range $=123-300 \mathrm{~kg} / \mathrm{ha}$ ), $78 \mathrm{~kg} / \mathrm{ha}$ (range = $0-150 \mathrm{~kg} / \mathrm{ha}$ ) and $50 \mathrm{~kg} / \mathrm{ha}$ (range = 12 $124 \mathrm{~kg} / \mathrm{ha}$ ), respectively. It was observed that majority of farmers practice over and under application of fertilizers than the blanket recommendation of the Department of Agriculture, Sri Lanka (Table 3). This heterogeneity of nutrient management by farmers could be a one of the reasons for the large variability of soil N, $\mathrm{P}$ and $\mathrm{K}$ levels. 
Table 2: Percentage of surveyed farmers in the three districts who received water from major and minor irrigation schemes and applied fertilizers in different frequencies.

\begin{tabular}{lccccc}
\hline \multirow{2}{*}{ District } & \multicolumn{5}{c}{ \% of farmers } \\
\cline { 2 - 6 } & \multicolumn{2}{c}{ Irrigation scheme } & \multicolumn{2}{c}{$\begin{array}{c}\text { Frequency of fertilizer } \\
\text { application }\end{array}$} \\
\cline { 2 - 6 } & Major & Minor & $\mathbf{3}$ & $\mathbf{4}$ & $\mathbf{5}$ \\
\hline Anuradhapura $(n=22)$ & 50 & 50 & 45 & 45 & 10 \\
Polonnaruwa $(n=24)$ & 100 & 0 & 29 & 67 & 4 \\
Kurunegala $(n=19)$ & 68 & 32 & 32 & 68 & 0 \\
\hline
\end{tabular}

(n: Number of farmers)

Adequate supply of irrigation water is one of the most limiting factors determining the yield of paddy and thus the nutrient removal from the soil. Further, irrigation water is a source of K supply for the paddy crop (Buresh et al., 2019). Majority of farmers in Polonnaruwa and Kurunegala districts are relying on irrigation water from major irrigation systems (command area is greater than 80 ha) in which the irrigation water supply is more reliable during the dry Yala season. But, in Anuradhapura district equal proportions of farmers depend on major and minor irrigation facilities. Minor irrigation systems depend on village tanks which are often abandoned during Yala season and shortages of adequate supply of water are experienced in the Maha season. Thus, this heterogeneity of the supply of irrigation water also has an influence on the variability of soil available $\mathrm{K}$ content.

The oxidation and reduction processes governed by the alternate flooding and drying of paddy soils directly influence the $P$ availability (Ponnamperuma, 1972). Thus, the spatial-temporal variation of oxidationreduction process resulted by the heterogeneity of the availability of irrigation water could contribute for the spatial variability of soil P levels observed in study areas.

Table 3: Percentage of surveyed farmers in the three districts who have applied high, low or recommended fertilizer rates.

\section{$\%$ of farmers}

\begin{tabular}{lccccccccc}
\cline { 2 - 9 } District & \multicolumn{3}{c}{$\begin{array}{c}\text { Apply higher rates } \\
\text { than recommended }\end{array}$} & \multicolumn{2}{c}{$\begin{array}{c}\text { Apply lower rates } \\
\text { than recommended }\end{array}$} & \multicolumn{3}{c}{$\begin{array}{c}\text { Apply recommended } \\
\text { rates }\end{array}$} \\
\cline { 2 - 10 } & Urea & TSP & MoP & Urea & TSP & MoP & Urea & TSP & MoP \\
\hline Anuradhapura & 41 & 14 & 23 & 45 & 82 & 73 & 14 & 4 & 4 \\
Polonnaruwa & 46 & 83 & 17 & 50 & 17 & 58 & 4 & 0 & 25 \\
Kurunegala & 32 & 26 & 16 & 58 & 63 & 68 & 10 & 11 & 16 \\
\hline
\end{tabular}

(TSP: Triple Super Phosphate, MoP: Muriate of Potash, Farmer fertilizer rates compared with DoA recommended levels for Urea, TSP and MoP, $225 \mathrm{~kg} / \mathrm{ha}, 55 \mathrm{~kg} / \mathrm{ha}$ and $60 \mathrm{~kg} / \mathrm{ha}$ respectively)

Further, soil organic matter is a major source of soil nutrients in paddy lands (Shaviv et al., 1985; Willet, 1991; Bijay-
Singh et al., 2004) and Vitharana et al. (2019) found a large spatial variability of soil organic $C$ in soils of Sri Lanka. This 
spatial variability of soil organic $C$ content can also be considered as a factor that determines the spatial-heterogeneity of soil nutrient levels. Rosemary et al. (2017) and Rathnayaka et al. (2018) showed that the short-scale spatial variability of soil texture has a direct influence on the variability of available $\mathrm{P}$ and $\mathrm{K}$ contents. Fairhurst et al. (2007) estimated an input of $14-20 \mathrm{~kg} \mathrm{~K}_{2} \mathrm{O}$ from the surface addition of 1 ton of rice straw. Thus, differences of paddy straw residue management and crop biomass yields could also determine the heterogeneity of K levels.

\section{Yield responses}

Variability of the yield data recorded from nutrient omission and ample treatments are shown in the Table 4. Paired sample $t$-test revealed a significant difference of yields between the ample $(5.8 \mathrm{Mg} / \mathrm{ha}, \mathrm{SE} \pm 0.2$ $\mathrm{Mg} / \mathrm{ha}$ ) and $\mathrm{N}$ omitted (3.9 Mg/ha, $\mathrm{SE} \pm 0.2$ $\mathrm{Mg} / \mathrm{ha})$ treatments $(p<0.05)$. The average yield of ample treatment was slightly higher than the $\mathrm{P}(5.7 \mathrm{Mg} / \mathrm{ha}, \mathrm{SE} \pm 0.2 \mathrm{Mg} / \mathrm{ha}$ ) and $\mathrm{K}$ (5.6 Mg/ha, $\mathrm{SE} \pm 0.2 \mathrm{Mg} / \mathrm{ha}$ ) omitted treatments and paired sample $t$-test revealed these differences are not significant $(p>0.05)$. Dobermann et al. (2003) reported similar trend of average yields in $\mathrm{N}(3.9 \mathrm{Mg} / \mathrm{ha}$ ), $\mathrm{P}(5.2 \mathrm{Mg} / \mathrm{ha}$ ) and $\mathrm{K}$ (5.1 Mg/ha) omitted treatments.

Figure 2 shows the relationships between yields of ample and nutrient omitted treatments. Higher yield in ample treatment than that of the nutrient omitted treatment shows a positive yield response. Except in three fields, a positive yield response for applied $\mathrm{N}$ was observed in all other fields (Figure 2a). However, results of the study did not show an obvious response for the applied P (Figure 2b) and K (Figure 2c).

Table 4: Summary statistics of gain yields in ample and nutrient omission treatments.

\begin{tabular}{lcccc}
\hline Treatment yield & $\begin{array}{c}\text { Mean } \\
\text { (Mg/ha) }\end{array}$ & $\begin{array}{c}\text { Min } \\
\text { (Mg/ha) }\end{array}$ & $\begin{array}{c}\text { Max } \\
\text { (Mg/ha) }\end{array}$ & $\begin{array}{c}\text { CV } \\
\text { (\%) }\end{array}$ \\
\hline N omission & $3.9 \pm 0.2$ & 0.9 & 7.6 & 38 \\
P omission & $5.7 \pm 0.2$ & 3.0 & 8.5 & 26 \\
K omission & $5.6 \pm 0.2$ & 2.8 & 8.3 & 27 \\
Ample & $5.8 \pm 0.2$ & 3.2 & 8.7 & 24 \\
\hline
\end{tabular}

(CV: Coefficient of variation, Min: Minimum, Max: Maximum)

This study revealed that available soil nitrogen levels of paddy grown soils are inadequate to produce expected yields. Thus, external supply of $\mathrm{N}$ by means of organic or inorganic fertilizer sources is required. $\mathrm{N}$ plays a critical role during the vegetative phase of paddy and required at all growth stages of the crop. But $\mathrm{N}$ loss from the paddy soil systems is faster than the other macronutrients, because of leaching, denitrification and volatilization (De Datta and Buresh, 1989). Higher losses of $\mathrm{N}$ ultimately cause lowering of nitrogen use efficiency and decreasing the profitability of cultivation. Improving the balance between the spatially varying indigenous $\mathrm{N}$ supplies and crop $\mathrm{N}$ requirements during the growth stages is essential to develop SSNM based recommendations. Several studies however have suggested that elevated $\mathrm{N}$ applications, as in ample treatment plots, can negatively affect the growth of paddy due to increased pests and disease attacks (Letourneau, 1988; Reddy, 2017).

Benefits of applying $\mathrm{P}$ and $\mathrm{K}$ fertilizers were not revealed in this study. Similar experiments conducted in paddy growing 
soils have revealed poor response for added $\mathrm{P}$ and $\mathrm{K}$ (Dobermann et al., 2003; Bandara et al., 2009; Wickramasinghe et al., 2009; Sirisena et al., 2013). Under redox condition, fixed $\mathrm{P}$ are released (reductive dissolution) and the $\mathrm{P}$ availability increases (Ponnamperuma, 1972; Pheav et al., 2005). Soil $\mathrm{P}$ in fixed forms generally regarded as adequate to supply the $P$ requirement of paddy for several seasons, depending on buffer capacity of the soil and P fertilizer management by the farmer (Sirisena and Suriyagoda, 2018). Low responsiveness for added $\mathrm{P}$ could also be related to the genotype (Aluwihare et al., 2016) or other soil conditions such as Zn availability (Singh and Singh, 1980) and Fe toxicity (Olalaye et al., 2001). Many paddy growing soils of Asia regarded as high in available $\mathrm{K}$ and found $\mathrm{a}$ significant input of $\mathrm{K}$ through irrigation water (Doberman et al., 1996; Buresh et al., 2019). This study showed a significant amount of $\mathrm{K}$ ranging from $42 \mathrm{~kg} / \mathrm{ha}$ to 89 $\mathrm{kg} / \mathrm{ha}$ (mean $=56 \mathrm{~kg} / \mathrm{ha}$ ) could be received by paddy fields through irrigation during a growing season (Table 5).

Table 5: Content of $\mathrm{K}$ in irrigation water and estimated supply $\mathrm{K}$ during a growing season in different areas of two districts.

\begin{tabular}{clcc}
\hline District & \multicolumn{1}{c}{ Area } & K content (mg/l) & K supply (kg/ha) \\
\hline Anuradhapura & Thuruwila & 4.6 & 55 \\
& Nachchaduwa & 4.2 & 50 \\
& Nachchaduwa & 4.4 & 53 \\
& Mahailuppallama & 4.0 & 48 \\
& Mahailuppallama & 4.8 & 58 \\
& Nachchaduwa & 4.3 & 52 \\
& Nachchaduwa & 6.3 & 76 \\
& Palugaswewa & 7.4 & 89 \\
Kurunegala & Padeniya & 3.5 & 42 \\
& Nikaweratiya & 4.0 & 48 \\
\hline
\end{tabular}

However, some studies have revealed higher yields in $\mathrm{P}$ and $\mathrm{K}$ applied fields and Fairhurts et al. (2007) showed timely supply of $\mathrm{P}$ is essential in $\mathrm{P}$ deficient soils for early growth stage and early flowering and ripening of paddy. Also $P$ increases the root growth and promotes the uptake $\mathrm{N}$ and other nutrients from the soil solution (Bowatte et al., 2006). Potassium plays a key role in transportation of water, nutrients and carbohydrates within the plants (Raheb and Heidari, 2011). Fairhurts et al. (2007) reported an increase of number of spikelets per panicle, filled grain percentage and thousand-grain weight under adequate supply of $\mathrm{K}$.

\section{Relationship between yield and available $P$ and $K$}

The relationship between yield response and available soil nutrients were investigated to identify the importance of initial soil $\mathrm{P}$ and $\mathrm{K}$ levels on yield response for added fertilizers (Figure 3). These scatter plots revealed that considerable variability of yield response $( \pm 2 \mathrm{Mg} / \mathrm{ha})$ in relation to soil $\mathrm{P}$ and $\mathrm{K}$ levels. Univariate regression analysis revealed no significant relationship between the yield response and available $\mathrm{P} \quad\left(\mathrm{R}^{2}=0.002\right)$ and $\mathrm{K}$ $\left(\mathrm{R}^{2}=0.019\right)$ levels. Thus, initial $\mathrm{P}$ and $\mathrm{K}$ levels of paddy growing soils are not indicative of the yield response for the added fertilizers. However, a considerable variability of the yield response in relation to the initial $\mathrm{P}$ and $\mathrm{K}$ levels (Figure $3 \mathrm{a}$ and $3 \mathrm{~b}$ ) suggested the need of further exploring the impact of other yield limiting factors such as, soil texture (Hamoud et al., 2019), soil pH (Moore et al., 1990), organic matter content ( Cassman et al., 1996; Sahrawat, 2005) micronutrients such as Zn (Buri et al., 2000), water availability. 

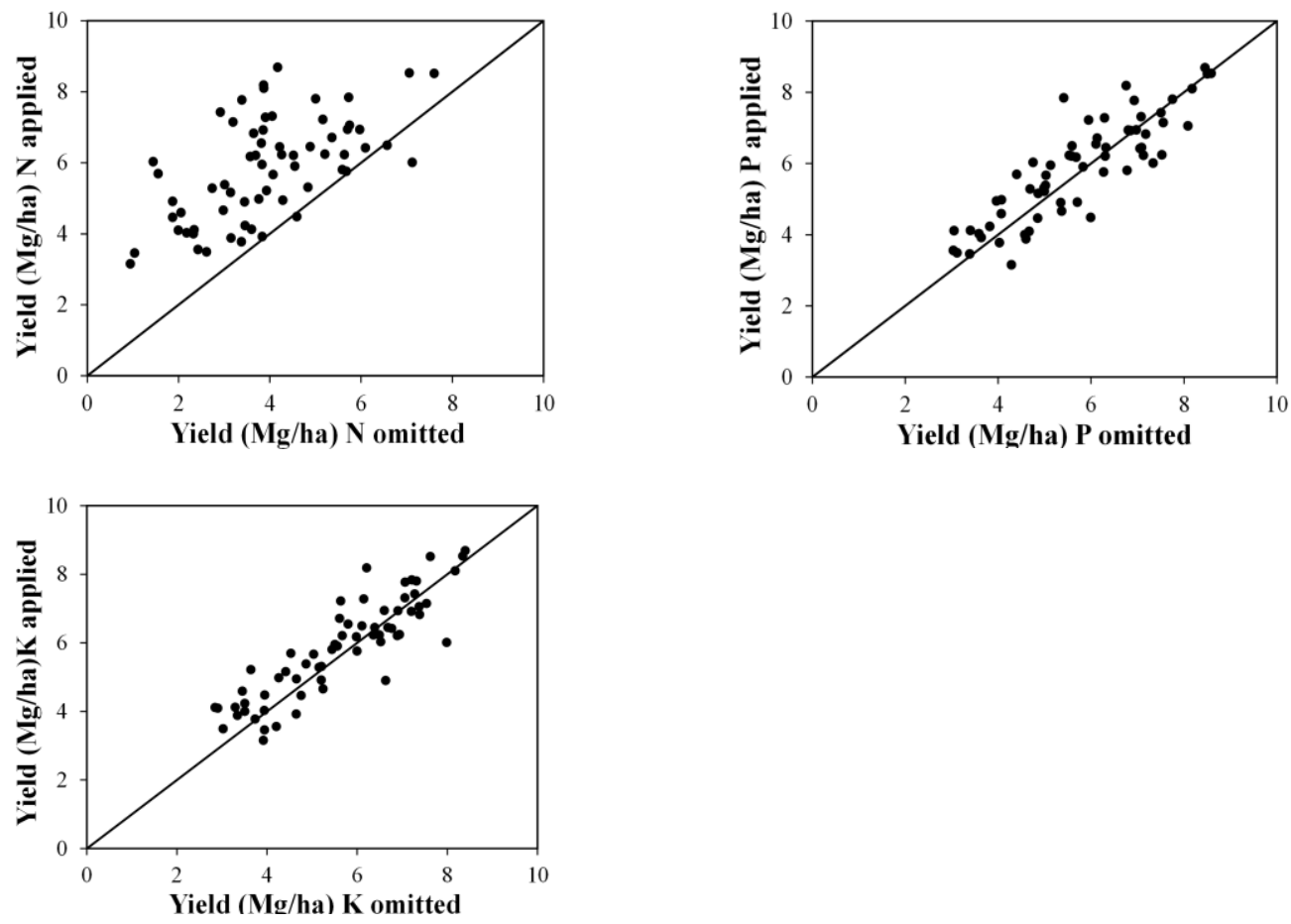

Figure 2: Yield response of paddy for (a) N, (b) P and (c) K fertilizer application

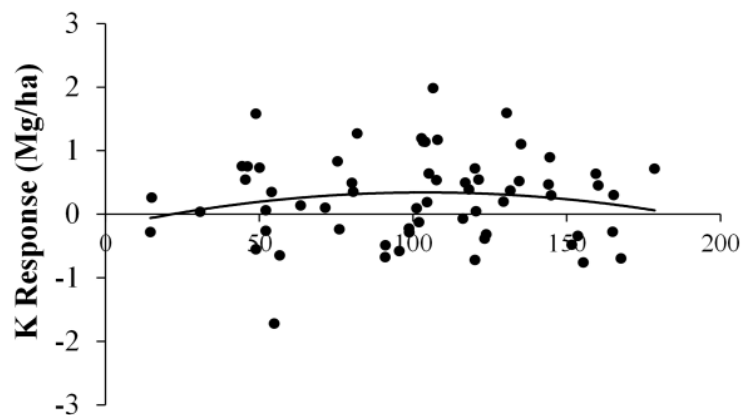

Initial Av. K(mg/kg)

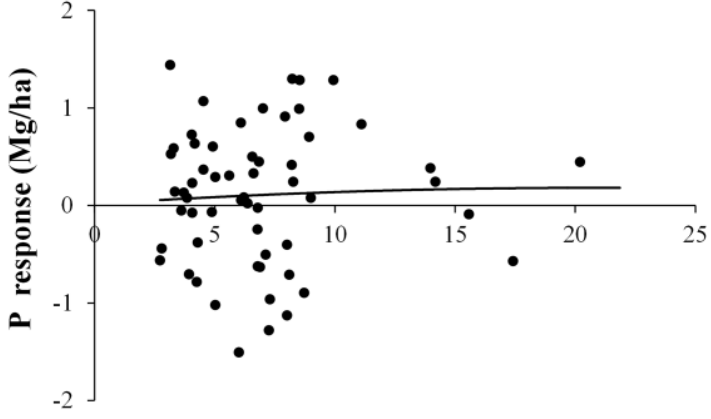

Initial Olsen P (mg/kg)

Figure 3: Relationship between yield response to available $P(a)$ and $K(b)$ in soil.

(Jearakongman et al., 1995) and growing season/climate (Yang et al., 2014) on yield response. Therefore, stepwise multiple linear regression models were fitted for yield response of $\mathrm{P}$ and $\mathrm{K}$ using factors namely, soil texture, soil $\mathrm{pH}$, soil EC, total carbon content, available $\mathrm{Fe}$, available $\mathrm{Mg}$, growing season and irrigation scheme (major/minor) together with initial $\mathrm{P}$ and $\mathrm{K}$ levels. The results of the multiple regression analysis indicated none of the yield limiting factors considered in this study determined the variability of yield response. Therefore, further studies are required to explore the causal factors determining the variability of yield response for added $\mathrm{P}$ and $\mathrm{K}$ observed in this study. Some researchers have questioned the applicability of conventional 
soil test methods when assessing the capacity of P supply in paddy soils (Sandesh et al., 1994; Dobermann et al., 1996).

\section{CONCLUSIONS}

Identifying the yield responses for major soil nutrients ( $\mathrm{N}, \mathrm{P}$ and $\mathrm{K}$ ) in paddy growing soils of Sri Lanka is important when determining SSNM decisions. The experimental sites of the three districts showed a large spatial variability of available soil $\mathrm{N}, \mathrm{P}$ and $\mathrm{K}$ levels. In addition to the inherent spatial variability of soils, the variability of farmers' practice in soil management could attribute for the variability of major nutrients. Yield response for added $\mathrm{N}$ revealed the importance of site-specific application of $\mathrm{N}$ to obtain higher yields. Though the average yield response showed a poor response for added $\mathrm{P}$ and $\mathrm{K}$ fertilizers, a considerable

\section{REFERENCES}

Aluwihare, Y.C., Ishan, M., Chamikara, M.D.M., Weebadde, C.K., Sirisena, D.N., Samarasinghe, W.L.G., and Sooriyapathirana, S.D.S.S. (2016). Characterization and selection of phosphorus deficiency tolerant rice genotypes in Sri Lanka. Rice Science. 23(4), 184 - 195.

Bandara, W.M.J., Wickramasinghe, W.M.A.D.B., Sirisena, D.N. and Wijewardana, J.D.H. (2009). Response of rice to applied potassium in soils of Sri Lanka. pp. 89102. In: Kumaragamage, D., Satyanarayana, T., Harmandeep-Singh and Majumdar, K. (Ed.) Use of phosphorus and potassium fertilisers in Sri Lankan Agriculture. International Plant Nutrition Institute (IPNI), Gurgon, Haryana, India.

Bijay-Singh, Yadvinder-Singh, Khind, C.S., Gupta, R.K., Meelu, O.P., Pasuquin, E. (2004). Long-term effects of organic inputs on yield and soil fertility in the rice-wheat rotation. Soil Science Society of America Journal. 68, 845853. variability of yield responses in relation to initial $\mathrm{P}$ and $\mathrm{K}$ levels and these variabilities were not related to intrinsic and extrinsic factors investigated in this study highlighting the need of assessing the other factors affecting the yield response. Better understanding on dynamics of soil $\mathrm{P}$ and $\mathrm{K}$ reserves and their spatio-temporal variabilities are required when formulating site-specific recommendations of $\mathrm{P}$ and $\mathrm{K}$.

\section{ACKNOWLEDGEMENT}

This study was financially assisted by the National Research Council of Sri Lanka through a target oriented research grant NRC/TO/16-07. Academic and the technical staff members of the Department of Soil Science, Faculty of Agriculture, University of Peradeniya was greatly acknowledged for the immense support given throughout the study.

Bowatte, S., Tillman, R., Carran, A. and Gillingham, A. (2006). Can phosphorus fertilisers alone increase levels of soil nitrogen in New Zealand hill country pastures? Nutrient Cycling in Agroecosystems. 75, 5766.

Buresh, R.J. (2015). Nutrient and fertilizer management in rice systems with varying supply of water, pp. 187-208. In: Drechsel, P., Heffer, P., Magen, H., Mikkelsen, R., Wichelns, D. (Eds.) Managing Water and Fertilizer for Sustainable Agricultural Intensification. International Fertilizer Industry Association (IFA), International Water Management Institute (IWMI), International Plant Nutrition Institute (IPNI), and International Potash Institute (IPI), Paris. France,

Buri, M.M., Masunaga, T. and Wakatsuki, T, (2000). Sulfur and zinc levels as limiting factors to rice production in West Africa lowlands. Geoderma. 94, 23-42. 
Buresh, R.J., Castillo, R.L., Torre, J.C.D., Laureles, E.V., Samson, M.I., Sinohin, P.J. and Guerra, M. (2019). Sitespecific nutrient management for rice in the Philippines: Calculation of fieldspecific fertilizer requirements by Rice Crop Manager. Field Crops Research. 239, 56-70.

Cassman, K.G., Dobermann, A., Sta Cruz, P.C., Gines, G.G., Samson, M.I., Descalsota, J.P., Alcantara, J.M., Dizon, M.A. and Olk, D.C. (1996). Soil organic matter and the indigenous nitrogen supply of intensive irrigated rice systems in the tropics. Plant and soil. 182, 267-278.

De Datta, S.K. and Buresh, R.J. (1989). Integrated nitrogen management in irrigated rice. In Advances in Soil Science, pp. 143-169. Springer, New York, NY.

Dobermann, A., Cruz, P.S. and Cassman, K.G. (1996). Fertilizer inputs, nutrient balance, and soil nutrient-supplying power in intensive, irrigated rice systems. I. Potassium uptake and $\mathrm{K}$ balance. Nutrient Cycling in Agroecosystems, 46(1), 1-10.

Dobermann, A., Cassman, K.G., Cruz, P.S., Adviento, M.A.A. and Pampolino, M.F., 1996. Fertilizer inputs, nutrient balance and soil nutrient supplying power in intensive, irrigated rice system. III. Phosphorus. Nutrient cycling in Agroecosystems. 46(2), 111-125.

Dobermann, A., Cassman, K.G., Mamaril, C.P. and Sheehy, J.E. (1998). Management of phosphorus, potassium, and sulfur in intensive, irrigated lowland rice. Field Crops Research. 56(1-2), 113-138.

Dobermann, A., Witt, C., Dawe, D., Abdulrachman, S., Gines, H.C., Nagarajan, R., Satawathananont, S., Son, T.T., Tan, P.S., Wang, G.H. and Chien, N.V. (2002). Site-specific nutrient management for intensive rice cropping systems in Asia. Field Crops Research. 74(1), 37-66.

Dobermann, A., Witt, C., Abdulrachman, S., Gines, H.C., Nagarajan, R., Son, T.T., Tan, P.S., Wang, G.H., Chien, N.V., Thoa, V.T.K. and Phung, C.V. (2003). Soil fertility and indigenous nutrient supply in irrigated rice domains of Asia. Agronomy Journal. 95(4), 913923.

Fairhurts, T., Witt, C., Buresh, R. and Dobermann, A. (2007). Rice: a pratical guide to nurient management. International Rice Research Institute, Manila, Philippines

Hamoud, Y.A., Wang, Z., Guo, X., Shaghaleh, H., Sheteiwy, M., Chen, S., Qiu, R. and Elbashier, M.M.A. (2019). Effect of irrigation regimes and soil texture on the potassium utilization efficiency of rice. Agronomy. 9, 1-17.

Jearakongman, S., Rajatasereekul, S., Naklang, K., Romyen, P., Fukai, S., Skulkhu, E., Jumpaket, B. and Nathabutr, K. (1995). Growth and grain yield of contrasting rice cultivars grown under different conditions of water availability. Field Crop Research. 44, 139-150.

Letourneau, D.K. (1988). Soil management for pest control: a critical appraisal of the concepts. In Proceedings of the Sixth International Science Conference of IFOAM on Global Perspectives on Agroecology and Sustainable Agricultural Systems, Santa Cruz, CA, 581-587.

Mallarino, A. P. (1995). Comparison of Mehlich-3, Olsen, and Bray-P1 Procedures for Phosphorus in Calcareous Soils. Proceedings of The Twenty-Fifth North Central Extension-Industry Soil Fertility Conference, Potash and Phosphate Institute, Manhattan, Kansas, 96-101. 
Moore, P.A., Attanandana, T., Patrick, W.H. (1990). Factors Affecting Rice Growth on Acid Sulfate Soils. Soil Science Society of America Journal. 54, 16511656.

Murphy, J.A.M.E.S. and Riley, J.P. (1962). A modified single solution method for the determination of phosphate in natural waters. Analytica Chimica Acta. 27, 31-36.

Olaleye, A.O., Tabi, F.O., Ogunkunle, A.O., Singh, B.N. and Sahrawat, K.L. (2001). Effect of toxic iron concentrations on the growth of lowlands rice. Journal of Plant Nutrition. 24, 441-457.

Pampolino, M.F., Manguiat, I.J., Ramanathan, S., Gines, H.C., Tan, P.S., Chi, T.T.N., Rajendran, R. and Buresh, R.J. (2007). Environmental impact and economic benefits of site-specific nutrient management (SSNM) in irrigated rice systems. Agricultural Systems. 93(13), 1-24.

Pheav, S., Bell, R.W., Kirk, G.J.D. and White, P.F. (2005). Phosphorus cycling in rainfed lowland rice ecosystems on sandy soils. Plant Soil. 269, 89-98.

Ponnamperuma, F.N., 1972. The chemistry of submerged soils. In Advances in agronomy. Academic Press. 24, 29-96.

Raheb, A. and Heidari, A. (2011). Clay mineralogy and its relationship with potassium forms in some paddy and non-paddy soils of nothern Iran. Australian Journal of Agricultural Engineering. 2, 169-175.

Rathnayaka, R.A.A.S., Vitharana, U.W.A., Balasooriya, W.K. (2018). Detailed mapping of soil texture of a paddy growing soil using multivariate geostatistical approaches. Tropical Agriculture Research. 29, 300-312.

Rathnayake, W.M.U.K., De Silva, R.P. and Dayawansa, N.D.K. (2015). Variability of some important soil chemical properties of rainfed low land paddy fields and its effect on land suitability for rice cultivation. Tropical Agricultural Research, 26(3), 506516.

Reddy P.P. (2017) Fertilizer Management. In: Agro-ecological Approaches to Pest Management for Sustainable Agriculture. Springer, Singapore.

Rosemary, F., Vitharana, U.W.A., Indraratne, S.P., Weerasooriya, R. and Mishra, U. (2017). Exploring the spatial variability of soil properties in an Alfisol soil catena. Catena. 150, 53-61.

Sahrawat, K.L. (2005). Fertility and organic matter in submerged rice soils. Current Science. 88, 735-739.

Shahandeh, H., Hossner, L.R. and Turner, F.T. (1994). Phosphorus relationships in flooded rice soils with low extractable phosphorus. Soil Science Society of America Journal. 58(4), 1184-1189.

Shaviv, A., Mohsin, M., Pratt, P.F. and Mattigod, S. V. (1985). Potassium Fixation Characteristics of Five Southern California Soils. Soil Science Society of America Journal. 49, 11051109.

Singh, M. and Singh, S.P. (1980). Zinc and phosphorus interaction in submerged paddy. Soil Science. 129, 282-289

Sirisena, D.N. (2013). Fertilizer recommendation for rice. Department of Agriculture, Peradeniya, Sri Lanka.

Sirisena, D.N., Jayawardena, N.P., Wickramasinghe, W.M.D.B., Rathnayake, W.M.U.K. and Mapa, R.B. (2008). Annals of the Sri Lanka Department of Agriculture. 10, 199210.

Sirisena, D.N., Herath, H.M.B. and Wanninayaka, W.M.N. (2013). Annals of the Sri Lanka Department of Agriculture. 15, 237-243. 
Sirisena, D.N. and Suriyagoda, L.D.B. (2018). Toward sustainable phosphorus management in Sri Lankan rice and vegetable-based cropping systems: A review. Agriculture and Natural Resources. 52, 9-15.

SPSS Inc. Released (2009). PASW Statistics for Windows, Version 18.0. Chicago: SPSS Inc.

Van Reeuwijk, L.P. (2002). Procedures for Soil Analysis (6 $6^{\text {th }}$ edition), Technical Paper No. 9. International Soil Reference and Information Centre, Wageningen, Netherlands. 1-21.

Vitharana, U.W.A., Mishra, U. and Mapa, R.B. (2019). National soil organic carbon estimates can improve global estimates. Geoderma. 337, 55-64.

Wickramasinghe, W.M.A.D.B., Sirisena, D.N., Bandara, W.M.J. and Wijewardana, J.D.H. (2009). Response of rice to application of phosphorus in soils of Sri Lanka. pp. 17-25. In: Kumaragamage, D., Satyanarayana, T., Harmandeep-Singh and Majumdar, K.
(Ed.) Use of phosphorus and potassium fertilisers in Sri Lankan agriculture. International Plant Nutrition Institute (IPNI), Gurgon, Haryana, India.

Willett, I.R. (1991) Phosphorus dynamics in acidic soils that undergo alternate flooding and drying pp. 43-49. In: Deturck, P. and Ponnamperuma, F.N. (Ed.) Rice Production of on Acid Soils of Tropics. Institute of Fundamental Studies, Kandy, Sri Lanka.

Witt, C., Dobermann, A., Abdulrachman, S., Gines, H.C., Guanghuo, W., Nagarajan, R., Satawatananont, S., Son, T.T., Tan, P.S., Simbahan, G.C. and Olk, D.C. (1999). Internal nutrient efficiencies of irrigated lowland rice in tropical and subtropical Asia. Field Crops Research. 63(2), 113-138.

Yang, J., Xiong, W., Yang, X.G., Cao, Y. and Feng, L.Z. (2014). Geographic variation of rice yield response to past climate change in China. Journal of Integrative Agriculture. 13, 1586-1598. 